\title{
Grain Quality of Rice (Oryza sativa L.) ‘Menthik Wangi' of Organic Farming Yields
}

\author{
Dwi Umi Siswanti ${ }^{1 *}$, Maryani ${ }^{2}$, Fitria Yulia Rachmawati ${ }^{3}$, Aprida Niken $^{3}$, Rega Virgiyana Agustin ${ }^{3}$, Niken Wulansari ${ }^{3}$ \\ ${ }^{1}$ Laboratorium of Plant Physiology, Faculty of Biology, Universitas Gadjah Mada, Yogyakarta, Indonesia \\ ${ }^{2}$ Laboratorium of Plant Structure and Growth, Faculty of Biology, Universitas Gadjah Mada, Yogyakarta, Indonesia \\ ${ }^{3}$ Undergraduate Student of Faculty of Biology, Universitas Gadjah Mada, Yogyakarta, Indonesia
}

ARTICLE INFO

Article history:

Received October 13, 2020

Received in revised form February 1, 2021

Accepted February 5, 2021

\section{KEYWORDS:}

Grain quality,

viability,

Menthik Wangi,

organic and rice

\begin{abstract}
Organic rice is believed to have better nutrition than rice conventional. Not all organic rice grain is consumed. Most of the organic cultivation yields will be used as seed. Viability test is one of the quality test of rice seed. Viability is seed vitality that can be shown as a physiological and biochemical phenomenon. Seed that have high vigor will achieve high productivity levels as well. The aims of this research was to analyze the quality of rice cultivar Menthik Wangi of organic farming yields. The quality of rice seeds was tested by measuring the viability of seed and crude fat content. The test results demonstrate the viability of the grain has a $100 \%$ germination, $100 \%$ growth potential maximum, $99.33 \%$, simultaneity grew, $\mathbf{9 7 . 3 3 \%}$ vigor index, $T_{50} 2.33$, and seed moisture content $10.67 \%$. The fat content was conducted by soxhlet method and analyzed by T-test. The results showed that organic rice has a higher fat content $(0.53 \%)$ than non-organic rice $(0.24 \%)$. It can be concluded that rice seed cultivar Menthik Wangi of organic farming has a higher viability and fat content than the non-organic rice grain.
\end{abstract}

\section{Introduction}

Organic farming is currently considered as an answer to the community's concern over the use of chemicals used in agricultural cultivation. That is because organic farming uses natural waste from animals or plants so it does not endanger the body. Although considered to be less practical, organically grown rice in general has better quality than non-organic rice (Priadi et al. 2007). However, based on research by Syamsudin and Aktaviani (2009), the application of organic fertilizer alone is not enough to significantly increase rice yields. The application of integrated crop management is also needed. Integrated crop management can include seed selection, soil management, seeding, fertilizing, irrigation, weed control, pests and diseases (Bobihoe 2007). Organic rice seeds or seeds must come from plants grown by organic farming systems for at least one generation or two seasons for annual crops (Nurhidayati et al. 2008).

Seed quality includes genetic, physiological and physical quality. Genetic quality of seed could determined by its degree of genetic purity, while physiological quality could determined by the rate of decline and

\footnotetext{
* Corresponding Author

E-mail Address: dwiumi@ugm.ac.id
}

seed vigor. Physical quality is determined by seed's cleanliness (Ichsan 2006). All stored seeds must have high growing strength so that they can germinate under various conditions. Seed vigor is associated in two information, viability and storability. Seeds that have high vigor will achieve high levels of productivity as well. High vigor is characterized by seed resistance to storage, pest attack, fast and evenly growing as well as being a normal, high-yielding mature plant in suboptimal conditions (Koes and Arief 2011).

Quality rice seeds require certain standardization. One of the rice seed quality tests is the rice seed viability test. Seed viability is the life force or ability of a seed shown as a result of physiological and biochemical phenomena. Seed viability testing is generally carried out using paper or sand substrates (Suwarno and Hapsari 2008). Rice seed viability test can be performed with the Sadjad method, namely by calculating seed water content based on the seed fresh weight, germination ability that illustrates seed potential viability, maximum growth potential which illustrates the total seed viability, simultaneous growth which is vigor seeds, vigor index (VI) which illustrates vigor for growing speed, and $\mathrm{T}_{50}$ is the time needed to reach $50 \%$ germination (Sutariati et al. 2014). Tests of crude fat content in rice are needed to differentiate varieties, soil fertility, colloidal structure, 
processing methods, fertilizer application, post-harvest storage time and other environmental conditions (Oko and Ugwu 2010; Oko et al. 2012; Yulia and Casper 2015).

Based on testing on several types of local and imported rice varieties cultivated in Ebonyi Nigeria, rice fat content was not significantly different and included in low levels, did not reach 1\% (Oko et al. 2012). But the rice proximate test that was cultivated in Abakaliki, Nigeria the results were significantly different. The difference depends on the ability of rice adaptation in various environmental conditions at the time (Oko and Ugwu 2010). Tarigan and Kusbiantoro (2011) said Menthik Wangi rice has a fat content of $0.23-1.41 \%$. The fat content of rice does not have a significant difference with the varieties of Pandan Wangi and Sintanur. The level of seed viability and rice fat content become a reference for the quality of rice seeds and the price level on the market. This study aims to determine the viability of seeds and crude fat content in rice seeds Menthik Wangi varieties that are organically cultivated in the research of Siswanti and Virgiyana (2014).

\section{Materials and Methods}

The research was conducted in August-November 2015 at the Green house of the Faculty of Biology, Laboratory of Chemistry and Biochemistry, Center for Food and Nutrition Studies (PSPG), Gadjah Mada University. The rice seeds used are the result of integrated organic farming in the village of Wukirsari, Cangkringan, Sleman.

Seed moisture uses the Sadjad method (Sutariati et al. 2014). Seed moisture content is calculated by the formula:

$$
\mathrm{KA}=\mathrm{m} / \mathrm{M} \times 100 \%
$$

KA : Water Content (seed)

$\mathrm{m}$ : The amount of water that is evaporated

( $\mathrm{m}$ = seed weight before drying - seed weight after drying at $105^{\circ} \mathrm{C}$ )

M : Seed weight before drying

Germination (GR) illustrates the potential viability of seeds. Germination is calculated by comparing the normal germinated seeds with the number of seeds planted, multiplied by $100 \%$ (Sutariati et al. 2014).

$$
\begin{aligned}
& \mathrm{GR}=\frac{n 1+n 2+\cdots+n i}{\mathrm{~N}} \times 100 \% \\
& \text { or } \\
& \mathrm{GP}=\frac{\sum \text { normal sprouts }}{\sum \text { seed planted }} \times 100 \%
\end{aligned}
$$
GR
: Germination rate
GP : Germination percentage (germination ability)
ni : Number of seeds germinated on day- $\mathrm{i}$
$\mathrm{N} \quad$ : Number of seeds tested

Maximum growth potential (MGP) illustrates the total viability of seed observed by counting all seeds that germinated on the last day of observation compared to the total number of seeds planted and multiplied by $100 \%$.

$$
\text { MGP }=\frac{\sum \text { germinating seed }}{\sum \text { seed planted }} \times 100 \%
$$

Germination uniformity is a seed vigor. GU is calculated by comparing the normal sprouts (KN) on the 5 days after planting and 7 days after planting or calculated based on the percentage of normal sprouts $(\mathrm{KN})$ on the day between the first count $\left(5^{\text {th }}\right.$ day after planting) and the second ( $7^{\text {th }}$ day after planting) which is on $6^{\text {th }}$ day after planting (Sutariati et al. 2014).

The Vigor Index (IV) illustrates the growth velocity which calculated by comparing the number of normal sprouts on the $5^{\text {th }}$ day after planting with the number of planted seeds multiplied by $100 \%$ or with the following formula:

$$
\mathrm{VI}=\frac{\sum \mathrm{KN}}{\begin{array}{l}
\text { first day of } \\
\text { calculation }
\end{array}}+\cdots \frac{\sum \mathrm{KN}}{\begin{array}{l}
\text { last day of } \\
\text { calculation }
\end{array}}
$$

or

$$
\mathrm{IV}=\mathrm{NX} / \mathrm{DX}
$$

VI : Index vigor

$\sum \mathrm{KN}$ : Number of seeds germinating normally

NX : Number of seeds germinated on day-X

DX : Number of days from the start germinating to the $\mathrm{X}^{\text {th }}$ day

$\mathrm{T}_{50}$ is the time needed to reach $50 \%$ germination, observed by counting the number of seeds that germinate every day (Sutariati et al. 2014).

$$
\mathrm{T}_{50}=\frac{\mathrm{ti}+(\mathrm{n} 50 \%-\mathrm{nj})(\mathrm{tj}-\mathrm{ti})}{n j-\mathrm{n}}
$$

$\mathrm{Tj} \quad$ : time between, after the seeds germinate $50 \%$

n50\% : number of seeds germinated 50\% of total germinated seeds

nj $\quad$ : number of seeds germinated at $\mathrm{tj}$

ni : amount of seeds germinates at ti time 
Determination of crude fat levels using the Soxletation Method (Horwitz 2000) Flour as much as 1.5 grams wrapped in coarse filter paper, put in the upper reservoir flask in a series of soxhlet devices. Petroleum ether solvent is put as much as $50 \mathrm{ml}$ into a previously weighed round flask. Extraction was carried out for 3 hours, then the solvent was evaporated in a drying oven. The fat extract is evaporated until fat deposits remain at the bottom of the pumpkin. Pumpkin is weighed again and obtained the difference between initial weight and final weight. The difference is the mass of fat, then the percentage is calculated.

\section{Results}

Measurement of rice seed viability in this study was carried out with the Sadjad method with several parameters, namely germination which illustrates seed potential viability, maximum growth potential (MGP) which illustrates total seed viability, germination uniformity (GU) is seed vigor, Vigor Index (VI) illustrates vigor grow speed, and $\mathrm{T}_{50}$ is the time needed to reach $50 \%$ germination and the calculation of seed moisture content is based on the wet weight of the seed.

The average water content of the Menthik Wangi rice seeds produced by integrated organic farming in Wukirsari Village was 10.67\% (Figure 1).

\section{Discussion}

In general, rice farmers do not have storage space for rice seeds in accordance with the standards to maintain viability because of limited costs. Testing rice seed germination through a viability test can help farmers to know the characteristics of rice seeds that are ready to be germinated and know the range of the number of rice seeds to be germinated in a certain area of land (Sutariati et al. 2014).

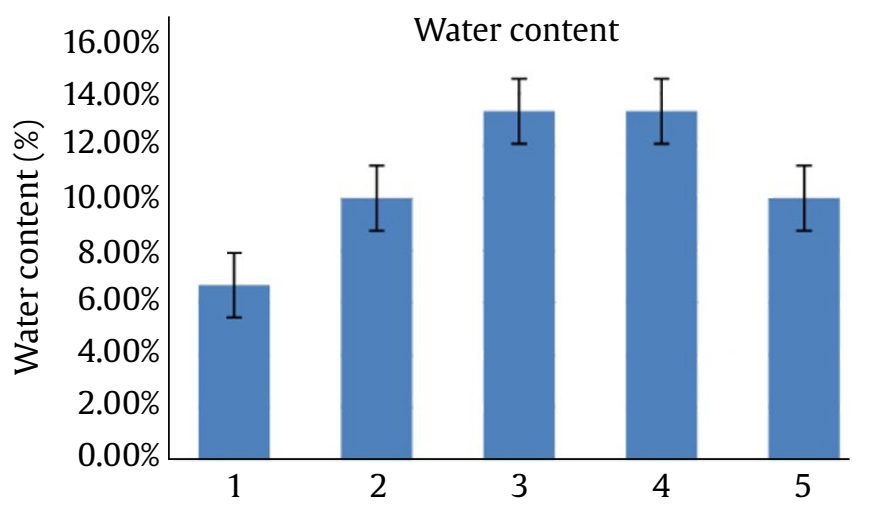

Figure 1. Water content of rice (Oryza sativa L) 'Menthik Wangi'
Seed moisture content (\%, w.b.) is conducted to determine the readiness of rice seeds to be germinated, if the rice seeds have high water content, it can be estimated that the seeds are composed of carbohydrates, proteins, lipids, and few nucleic acids. This can result in germination failure because high water content can cause seed rottenness. Low seed water content can accelerate the germination process, especially carbohydrates in endosperm which will be overhauled into reducing sugars to be transferred to seed embryos as an energy source for germination.

The water content is good for orthodox seeds such as rice seeds. The moisture content of rice seeds depends on the post-harvest drying time and storage method. The Menthik Wangi rice seeds have been stored by researchers for 12 months after drying in the sun for 3 days. Low moisture content of Menthik Wangi rice seed causes high levels of protein, carbohydrates, and lipids and indicates that the rice is ready for germination. The moisture content value of Menthik Wangi rice seeds is lower than the standard water content value, which is a maximum of $13 \%$, which means that Menthik Wangi's rice seeds are ready to be germinated quite high (Figure 1).

Seed moisture content can be used as a reference for seed storage so that viability is maintained. Good storage space conditions for orthodox seeds, including rice; is in dry and cold conditions. The seeds of the orthodox group are characterized by their nature which can be dried without damage to the embryo and its endosperm, the viability of the orthodox seeds does not experience a significant decrease with a decrease in water content to below $20 \%$, so that orthodox type seeds can be stored in the condition of seeds with low water content (Syamsudin and Aktaviyani 2009).

The simultaneity of Menthik Wangi rice seed germination from integrated organic farming showed that on the $7^{\text {th }}$ day there was a simultaneous germination of 50 rice seeds (Figure 2). Germination

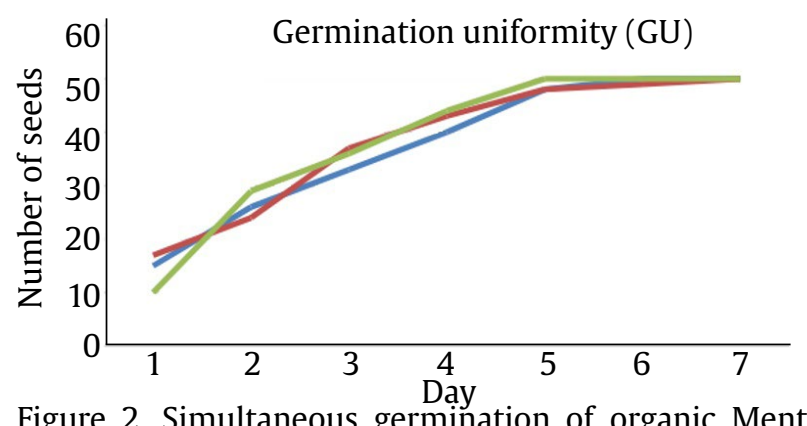

Figure 2. Simultaneous germination of organic Menthik Wangi rice seeds 
uniformity (GU) is rice seed vigor. The Menthik Wangi's grain has a high Germination uniformity ( $\mathrm{GU}=99.33 \%$ ). It showed rapid and uniform growth and development of sprouts. Vigor Index (IV = 97.33\%.) illustrates growth speed. The Vigor Index shows Menthik Wangi rice seeds have a high rate of growth into new individuals. $\mathrm{T}_{50}$ is the time needed to reach $50 \%$ germination. $T_{50}=2.33$ (days), it means that Menthik Wangi rice seeds need 2.33 days to germinate up to $50 \%$ or half of the number of rice seeds that are germinated.

There are differences among plot in simultaneity to reach $\mathrm{T}_{50}$ which can be caused by differences in the level of viability in each seed used, even though the germination (DB) is $100 \%$. Each seed has factors that reduce the level of viability, for example the speed of the endosperm reshuffle process, the process of transfer to the embryo, endosperm thickness, aleurone sensitivity, the gibberelline hormone in the seeds and the process of water imbibition to initiate the germination process. Low water content (\%, w.b.), germination rate (GR), vigor index (VI) and high germination (GP) with $\mathrm{T}_{50}=2.3$ days shows that Menthik Wangi organic rice seeds have high viability.

Crude fat test is one part of the proximate test. The sample is given a non-polar solvent, then the solvent is evaporated until the remaining fat, the fat is called crude fat (Midwest Laboratories 2015). Usually crude fat can be extracted with ether, chloroform and butanol (The Rice Associationn 2015). The crude fat content of Menthik Wangi rice as a result of integrated organic farming compared to non-organic Menthik Wangi rice. The measurement results show organic rice has a higher fat content (0.53\%) compared to non-organic rice $(0.24 \%)$. This shows that the content of microbial agents in biofertilizers given in integrated organic farming can provide better nutrients. Adequate nutrients in the growing media increase glucose. Increased glucose increases the conversion of glucose into acetyl co-A which is then converted to fat through fat synthesis. Coarse fats in plants are unsaturated fats, which are fats that have a double bond on the carbon chain. Unsaturated fats can reduce blood cholesterol levels, so it is good for health. The most fat in rice is in the spherosomes in the aleuron layer. However, the layer usually disappears during the grinding process. Nevertheless, around $1.5-1.7 \%$ of total rice fat still remains in milled rice (Oko et al. 2012).

\section{Conclusion}

Based on the research of the viability and crude fat content of Menthik Wangi rice seeds from the integrated organic farming, the Menthik Wangi organic rice seeds have high viability and higher crude fat content compared to non-organic rice seeds.

\section{Acknowledgements}

Thanks to Final Assignment Recognition Grant Universitas Gadjah Mada and Research Institute and Community Service (LPPM) Universitas Gadjah Mada.

\section{References}

Bobihoe J. 2007. Pengelolaan Tanaman Terpadu (PTT) Padi Sawah: Inovasi Teknologi untuk Meningkatkan Produktivitas Tanaman Padi. Jambi: Balai pengkajian pertanian jambi.

Horwitz W. 2000. Official Methods of Analysis of AOAC International. 17th ed. Gaithersburg: AOAC International.

Ichsan CN. 2006. Uji viabilitas dan vigor benih beberapa varietas padi (Oryza Sativa L.) yang diproduksi pada temperatur yang berbeda selama kemasakan. $J$ Floratek 2:37-42.

Koes F, Arief R. 2011. Pengaruh Perlakuan Matriconditioning terhadap Viabilitas dan Vigor Benih Jagung. Seminar Nasional Serealia 2011. Balai Penelitian Tanaman Serealia.

Midwest Laboratories. 2015. Midwest memo: crude fat analysis. Available at: www.midwestlabs.com [Date accessed: 15 August 2019]

Nurhidayati I et al. 2008. Pertanian Organik-Suatu Kajian Sistem Pertanian Terpadu Dan Berkelanjutan. Program Studi Agroteknologi. Jurusan Budidaya pertanian. Fakultas Pertanian. Universitas Islam Malang.

Oko A, Ugwu SI. 2010. The proximate and mineral compositions of five major varieties in Abakaliki, South-Eastern Nigeria. International journal of plant physiology and biochemistry 3:25-27.

Oko A et al. 2012. Comparative analysis of the chemical nutrient composition of selected local and newly introduced rice varieties grown in ebonyi state of nigeria. International journal of agriculture and forestry 2:16-23.

Priadi D et al. 2007. Padi organik versus non organik: studi fisiologi benih padi (Oryza sativa L.) kultivar lokal rojolele. Jurnal ilmu-ilmu pertanian indonesia 9:130138.

Siswanti DU, Agustin RV. 2014. Respons fisiologis padi (Oryza sativa L.) "Segreng" dan "Menthik Wangi" terhadap aplikasi pupuk organik cair dan dekomposer. BIOGENESIS 2:89-93.

Sutariati GAK et al. 2014. Invigorasi benih padi gogo lokal untuk meningkatkan vigor dan mengatasi permasalahan dormansi fisiologis pascapanen.Jurnal Agroteknos 4:10-17.

Suwarno FC, Hapsari I. 2008. Studi alternatif substrat kertas untuk pengujian viabilitas benih dengan metode uji UKDdp. Bul Agron 36:84-91. 
Syamsudin TS, Aktaviyani S. 2009. Penerapan pemupukan pada pertanian padi organik dengan metode system of rice intensification (SRI) di desa sukakarsa kabupaten tasikmalaya. Jurnal agroland 16:1-8.

Tarigan BT, Kusbiantoro B. 2011. Pengaruh derajat sosoh dan pengemas terhadap mutu beras aromatik selama penyimpanan. Penelitian pertanian tanaman pangan 30:30-36.
The Rice Association. 2015. Rice: Nutritional Profile and GI Implications. Available at: www.thericeassociation. org.uk [Date accessed: 28 Agustus 2015]

Yulia R, Casper SA. 2015. Pengaruh penyimpanan terhadap kualitas beras: Perubahan sifat kimia selama proses penyimpanan [Skripsi]. Semarang, Indonesia: Universitas Diponegoro. 